\title{
Rectifying the Civil-Military Imbalance-What Pakistan Can Learn From the Turkish Experience
}

\author{
Maheen Saleem Khosa \\ Forman Christian College, Lahore, Pakistan \\ maheensaleem@fccollege.edu.pk
}

\begin{abstract}
Historically, in both Pakistan and Turkey, the military has been deeply involved in the politics of the state. Civilian governments have had to contend with the influence of the military in politics and have often been undermined and overthrown. However, the Prime Minister-ship of Recep Tayyip Erdogan is often quoted as an example in Pakistan of how to successfully rectify the imbalance between the civilian governments and the military. This paper discusses the Turkish experience and what Pakistan can learn from it - its successes, pitfalls and applicability to the Pakistani milieu. The paper considers whether Mr. Erdogan has truly succeeded in recalibrating the civilian-military equation and whether the Pakistani political scene allows for similar results. A particular point of resonance is the trial of former coup leaders in Turkey and the current trial in Pakistan of General (retd.) Pervez Musharraf (who led the last coup) for treason. It is an open question whether these trials undermine military influence or breed greater motivation to intervene (especially where they are seen not to be fair) and in what circumstances? Pakistan stands at a critical juncture with a recent, historic civilian transition of power. The Turkish experience therefore provides valuable lessons.
\end{abstract}

Keywords: Turkey, democracy, civil-military imbalance, Pakistan, military coups

\section{Introduction}

The politics of both Turkey and Pakistan have historically been characterized by significant military involvement in the affairs of the state. However, the past decade has seen significant shifts in the politics and particularly the civil-military dynamics in both countries. Turkish politics has undergone major shifts during the Prime Minister-ship of Recep Tayyip Erdoğan. The most significant of these have been the trials in 2007 of over three hundred senior military personnel, accused of seeking to overthrow the government in 2003. Irrespective of the actual and perceived irregularities in the trials, just the fact of them was unprecedented. It was also thought to be indicative of a paradigm shift in the politics of a country long defined by its civilmilitary imbalance. Pakistan - with its troubled civil-military dynamic and history of coups - has eerie parallels to the Turkish example. The country recently achieved a milestone in its democratic development with one democratically elected government completing its tenure and passing over to the next, for the first time in Pakistan's 67 year history. Given the extent of military involvement in the past and the country's failed experiment with democracy in the 1950s and the 1990s, this was cause to be hopeful. However, the ongoing trial of former President and retired General Pervez Musharraf (who led a coup in 1999 and remained in power till 2008) has thrown up its own unique set of challenges and questions. Many of ex-President Musharraf's protagonists have perhaps been able to successfully paint it as a scapegoating exercise rather than any realistic attempt to rectify the civil-military imbalance in the country or restore constitutional supremacy.

These factors lead to the obvious question as to whether these two countries - with their deeply praetorian history - could finally be moving towards democratic consolidation. While the events of the past year ${ }^{1}$ have

\footnotetext{
${ }^{1}$ The AKP government lost some credibility and came under fire when a corruption scandal erupted in December 2013, leveling charges of corruption against then Prime Minster Erdoğan and several members of his cabinet. The case, although recently dismissed by Turkish prosecutors, was one of the biggest challenges faced by Erdoğan in his 11 year rule. Erdoğan faced significant domestic and international criticism for his response - tightening control of the internet, banning Twitter for two weeks, and reassigning a number of prosecutors, judges and police. The scandal also created
} 
rendered that question premature, it is worth questioning a) whether the historically lopsided civil military dynamic could be balanced; and b) whether the era of direct military intervention and coups is over in both countries. This paper studies the changing nature of civil-military relations in Turkey and Pakistan, particularly in the past decade. In particular, it will focus on the trials of former coup leaders in both countries as a particular point of resonance. Given the differences in the individual context of both countries, it will stop short of drawing a direct comparison between the two; however, it will assess the Turkish experience from the perspective of what Pakistan can learn from it - both the successes and potential pitfalls.

Turkey \& Pakistan: Modern Praetorian States: In a modern praetorian state, the military plays a dominant role in political structures and institutions. The political processes of this state favor the development of the military as the core group and the growth of its expectations as a ruling class; its political leadership (as distinguished from bureaucratic, administrative, and managerial leadership) is chiefly recruited from the military, or from groups sympathetic, or at least not antagonistic, to the military. Constitutional changes are effected and sustained by the military, and the army frequently intervenes in the government (Perlmutter, 1969, p. 383). There is a detailed typology of the different types of praetorian militaries but for our purposes, there are two that are relevant: the arbitrator militaries and the parent-guardian militaries. The first type will periodically acquire power but shirk away from holding on to it for too long. Parent-guardian militaries are known for institutionalizing their political power through constitutional and legal provisions. The military in this case justifies the institutionalizing of its power as a prerequisite for strengthening democracy. Pakistan and Turkey are both arbitrator militaries that have evolved to become parent-guardian militaries. The inclusion of senior generals in decision making at the highest level of the government is meant to serve as a firewall against any irresponsible behavior by the civilian leadership, as has been done through the establishment of National Security Councils (NSC) in both Turkey and Pakistan (Siddiqa, 2007, pp. 51-57).

The question is what causes militaries in praetorian states to intervene? And what are the circumstances under which they abstain from interventionism? The most important factors explaining the decision of military officers to discontinue direct control over the government include the performance of the civilian government in domestic affairs, the institutional interests of the military, and the availability of an acceptable civilian alternative to military rule. Performance failures by a military government inevitably lead to legitimacy deflation and will mobilize civilian sectors against continued military rule. On the other hand, successful achievement of the goals set by the military can also generate domestic pressure for them to relinquish control over the government, now that their original task has been completed. Pressure for a return to traditional military duties frequently arises from within the military itself as policy differences within the military leadership cause factionalism. Factionalism, combined with loss of prestige from poor performance as governors, could generate enormous pressure on the military leadership to withdraw and attend to its own institutional concerns. Finally, the military is unlikely to relinquish power unless an acceptable civilian alternative is available (Singh \& Hickman, 2013, p. 39). In terms of perception of militaries in civilian quarters, a military's tutelary norms and beliefs tend to survive the eclipse of authoritarian structures because the institutional processes that produce them remain unaffected by military disengagement from government (Shah, 2014, p. 211). Moreover, how militaries interpret civilian reforms and whether they consider political subordination inherently legitimate are crucial ingredients in the success of civilian democratic regulation of the armed forces. In other words, the long term success of democracy is intrinsically linked to changing the military's tutelary beliefs (Shah, 2014, p. 276).

\section{Civil-Military Imbalance: The Context}

In order to answer the questions posed by this paper, and particularly to examine what Pakistan can learn (to replicate and to avoid) from the Turkish experience, it is important to isolate the points of confluence and divergence between the contexts in which the militaries of both countries came to be the dominant institution

doubt regarding the AKP's performance in the March 30th, 2014 Municipal elections in Turkey, although these later proved to be unfounded. In Pakistan, the Pakistan Muslim League - Nawaz (PMLN) government has been rocked with accusations of electoral rigging, and a protest movement led by the opposition party Pakistan Tehreek-e-Insaaf (PTI) calling for Prime Minister Nawaz Sharif to resign. The accusations bring into question the legitimacy of the current government. 
in its political affairs and how it has affected their response to the trial of their leaders. Therefore, it is important to understand the context in which the militaries have both existed and their historical role in the state.

Both the Pakistani and the Turkish militaries established their institutional pre-eminence in the early years of their respective republics and have since arrogated to themselves a tutelary role over the political and economic affairs of the state (Singh \& Hickman, 2013, p. 39). Further, both militaries - although dramatically opposed in their specific place along the religion-secular spectrum - have also historically considered themselves to be the guardians of their countries' ideological frontiers. For Turkey, this was more straightforward with the military becoming the defenders of Kemalism - the ideology put forth by the founder of the modern republic, and military hero, Mustafa Kemal Atatürk - the preservation of which was the overarching concern of the military and became the raison d'être for the military's intervention in politics whenever it deemed that there was a threat to it. In Pakistan, this was more nebulous with the military not backing any specific ideology for the affairs of the state except during the overt dictatorship of Gen. Zia-ulHaq from 1979 to 1988 when he led an official campaign to "Islamize" Pakistan. Instead, the military in Pakistan is seen to have certain ideological positions in relation to the foreign policy of the state, the reorientation of which, without the consent of the military has not been deemed acceptable. Therefore, military coup leaders in Pakistan have not cited the threat to an ideology for the reasons for their coups rather have cited excessively poor governance and mal-administration on the part of the civilian dispensation.

Therefore, because the military has been the setter and then the defender of the republic's foundational ideology, civilian politicians in Turkey have always had to contend with the overarching presence of the military in the politics of the state (Kuru, 2012, pp. 37-38). Since the creation of the Republic of Turkey in 1923, the country has witnessed three direct military coups against democratically elected governments 1960, 1971 and 1980. The 1960 and 1980 interventions were classic interventions in which the military proceeded to rule before transferring power to civilian governments (Aydinli, 2011). In 1971, the military did not rule directly, instead it chose to appoint several caretaker parliaments until a president was elected by the parliament in 1973. Most recently, in 1997, Turkey faced an indirect, more evolved sort of intervention, labeled by some as a "post-modern" coup (Aydinli, 2011, pp. 228-29). The military facilitated and encouraged a societal reaction against the Islamic Welfare Party led government leading to mass anti-government protests (Aydinli, 2011). Within this context, the military, through the NSC issued a series of "recommendations" for the government to accept, which ultimately led to the resignation of then Prime Minister Necmettin Erbakan (AlJazeera, 2012).

Despite their continued interference in a realm traditionally thought to be civilian, the Turkish military has historically enjoyed enormous prestige in Turkish society as well, beyond merely their institutional dominance (Singh \& Hickman, 2013). There are a number of reasons for this. The first goes back to the prestige the military accumulated in defeating the Armenian and Greek armies in the War of Independence against the Allies in World War 1. The Republic's first president, Kemal Atatürk, a military hero, became the embodiment of the hopes and aspirations of the new republic he had helped to midwife (Singh \& Hickman, 2013). The second reason for the military's position in society is the historic mistrust in politics and civilian politicians and the somewhat circular belief that the military will step in to save the day when things go wrong (Aydinli, 2009, pp. 581-82). Third, societal loyalty to the military may also exist because Turkey has a conscript military (Aydinli, 2009, p. 582). Five years after the army browbeat Turkey's pro-Islamic government into stepping down, a new party - the Justice and Development Party (AKP) - rooted in the same movement swept into power in the elections in November 2002. The party won 34 percent of the vote, giving it 363 of the 550 seats in parliament. This win was largely credited to Recep Tayyip Erdoğan. Credited as being Turkey's most effective leader and political operator since Atatürk, Erdoğan's charisma was a much more potent force in the elections than AKP's vague conservative-religious ideology (Pope, 2011, pp. 322-23). Under his leadership, the AKP brought many political groups into its fold - Islamists, Turkish nationalists, Kurds, rural conservatives, Muslim sect members and globalized liberals (Pope, 2011, pp. 322-23).

Once in power, Erdoğan began tackling some of Turkey's most pressing challenges - the economy, the European Union question and constitutional reform. He identified the challenge posed by Europe, and the changes required by it from Turkey as his benchmark. On $17^{\text {th }}$ December 2004, when the European Union 
finally gave Turkey a date to start talks on future membership after 40 years of an uneasy courtship, it was considered to be one of the most important days in modern Turkish history (Morris, 2006, p. 1). Erdoğan came back from the summit in Brussels to a rousing reception (Morris, 2006, p. 1). Coming in to power on the heels of the worst economic collapse Turkey had seen in decades, many, particularly from the big business and finance community in Istanbul, were skeptical of Erdoğan's ability to fix the economy, but most have been won over by his actions (Morris, 2006, pp. 162-63). Although progress is still not complete, there were signs of progress from the beginning i.e. in 2004, for the first time since September 1972, inflation dropped to single figures (Morris, 2006, pp. 162-63). In terms of constitutional reform, at the time of its electoral victory in 2002, the AKP held an almost two-thirds majority, which was enough for the government to be able to change the Constitution on its own (Pope, 2011, pp. 322-23). Continuing the series of constitutional amendments that began in 2001, the AKP government spearheaded the most significant set of reforms in 2010, curbing the power of the military over politics. These included, among others, overhauling the Constitutional Court, restructuring the Supreme Board, limiting the authority of military courts and imposing judicial review against all decisions taken by the Supreme Military Council (Bilgin, 2010). While the first two contrived to build capital with society in general, the successful passage of these amendments in particular were indicative of the changing nature of the civil - military imbalance.

Pakistan's history of military coups dates back to 1958 when the first constitutionally elected government was removed, its first ever constitution abrogated and martial law imposed in the country. Field Marshal Ayub Khan deposed then President Iskandar Mirza (who, ironically, had abrogated the Constitution and asked the armed forces to intervene to begin with!) and became President. A new constitution was promulgated in 1962, and Ayub Khan was elected as President again in controversial indirect elections held in 1965. His reign lasted until 1969 at which point martial law was again imposed in the country under General Yahya Khan. After the war in 1971 that saw East Pakistan became the independent state of Bangladesh, a new Constitution was promulgated in 1973 and the Pakistan People's Party led by Zulfiqar Ali Bhutto swept into power2. The country's subsequent experiment with democracy lasted only until 1977. In the aftermath of elections held in 1977, there were nation-wide protests alleging that the elections had been rigged by the incumbent government. After a protracted and prolonged period in which no resolution to the protests could be found between the political parties, the military led by General Zia-ul-Haq launched a military coup and thus began Pakistan's third martial law in its thirty year history. This lasted until 1988. The next 11 years were Pakistan's next foray into democracy and a time when the military was not directly involved in politics. However, not a single government was allowed to complete its tenure during these 11 years. A sequence of weak democratic governments culminated in the 1999 military coup by then Chief of Army Staff Pervez Musharraf, who proceeded to rule till 2008.

Contrary to the Turkish example, Pakistan's military played no role in the independence of the country. The perception of the armed forces in society therefore varies from that of the Turkish military. As opposed to the kind of prestige associated with the Turkish military, there is a perception of necessity attached to the Pakistani military which stems historically from its external threat perception, particularly a continued state of conflict with India. More recently, this threat perception has come to include the perception of India's influence in Afghanistan as well as the internal security paradigm, with domestic terrorism increasing the necessity of the military. Ironically, however, the sense that the military (and the USA) is responsible at some level for the creation and sustenance (during the Cold War era) of the groups that have emerged as terrorists threats has also led to greater criticism of the military. Nonetheless, lingering territorial disputes and a hostile security environment have committed Pakistan to strengthening its armed forces and added to their charismatic appeal. Additionally, this has afforded the military flexibility in defining Pakistan's national security interests in a manner that strengthened its position vis a vis civilian institutions (Sattar, 2001, p. 390). Delving deeply into traditionally civilian spheres, the military has a pervasive role in education and training, health and medical services, disaster management, logistics, construction, transportation and the industrial sector making it more influential and resourceful than any civilian institution of the state (Sattar, 2001, pp. 409-12). The historic failure and ineptitude of civilian governments has led to the creation of the military's role as a savior of the last resort - to step in and save the day when yet another civilian government messes up.

2Bhutto served as Chief Martial Law Administrator for a period of time as well. 
After an initial honeymoon period - with the traditional savior rhetoric associated with military coups - the later years of the Musharraf era resulted in a significant loss of professional repute for the military in society as they coincided with an increase in domestic terrorism, and because of the political agitation towards the tail end of his tenure. As political and professional costs mounted, the military leadership sought to regain the trust and confidence of the people. In the post-Musharraf era, it seemed as though the military elite reassessed and re-strategized their role and relationship with the civilian leadership. On occasion, they also appeared to show "deference" to the political leadership (Shafqat, 2011, pp. 50-53). Despite occasional crises and the historically unstable relationship between the Pakistan Peoples Party and the military, these were seen to be indications that the civil military equation was going through a transformative phase. The government also successfully passed the $18^{\text {th }}$ amendment to the Constitution which amended Article 6 of the Constitution to make any constitutional arguments for future military interventions more difficult ${ }^{3}$. With country's first ever successful civilian transition, there was perhaps just cause to believe that Pakistan had moved a step closer to exiting the dreaded era of the coup d'etat.

Military Trials - Ergenekon, Musharraf: Part of the constitutional reforms agenda passed by the Erdoğan government in 2010 was an amendment that stripped members of the Council of National Security of the historic immunity from prosecution they had enjoyed under the 1982 constitution ${ }^{4}$ (Cook, 2012). In addition to the symbolic and future implications of this amendment, the door also opened towards past reckoning. In April 2012, just over thirty years after the coup thought to be the bloodiest in Turkey's history, an Ankara court began hearing cases against the last surviving architects of the 1980 coup, retired General Kenan Evren, 94 and former air force commander Tahsin Sahinkaya, 87. Erdoğan's government, the opposition and parliament joined nearly 350 individuals and groups as co-plaintiffs in the trial as aggrieved parties. In June 2014 , both men were sentenced to life imprisonment for their role in orchestrating the coup. The trial and the verdicts were largely symbolic given the advanced age of both defendants but were unprecedented - not just in Turkey but in states with similar praetorian outlooks. Moreover, the fact that the plaintiffs represented such a varied collection of groups from society indicated the evolution of Turkish society in its perception of the military as guardians and saviors of the state.

While a milestone in itself, these trials did not say much about the response of the military to some of their own being put to task. This became more of a factor in the so-called Ergenekon case. Launched in 2007 after an anonymous tip led to the discovery of an arms cache in Istanbul, the Ergenekon case has since then expanded into a broader case comprising a total of 275 defendants. The defendants were accused of plotting to overthrow the government in 2003 and the defendants were made up of a group of staunchly secular, nationalist, high ranking military officers including Ilker Başbuğ, a former Chief of General Staff, top bureaucrats, academics and journalists. Of those convicted, 17 people received life sentences; Ilker Basbug and 13 others were high ranking military officers (Dalay, 2013). The Ergenekon case and its consequent verdict were significantly controversial. Given the interventionist history of the Turkish army, it was plausible that elements in the top echelons of the army were potentially planning to overthrow the government. However, significant issues arose with the conduct of the trials. The evidence was dubious in some cases, and non-existent in others. Many of Erdoğan's political opponents are in jail, including opposition politicians. The fear, then, was that in a bid to curtail the authoritarianism and interventionist tendencies of the military, Erdoğan had become similarly autocratic. Despite this, just the fact of these trials as well was unprecedented. What was even more critical in this case is that the military not only allowed these trials and indictments to take place, but there is evidence that they would have been able to continue without the cooperation of sections from within the military itself. This is indicative of a change emerging from within the military itself

3Prior to the 18th amendment, Article 6 prohibited the abrogation of the Constitution. To get around this, the military would often hold the Constitution "in abeyance" thereby arguing that they had not "abrogated" it. Through the 18th amendment, Article 6 was amended to specifically include holding the Constitution "in abeyance" in the definition of high treason.

${ }^{4}$ Provisional Article 15 stated that, "No allegation of criminal, financial or legal responsibility shall be made, nor shall an application be filed with a court for this purpose in respect of any decisions or measures whatsoever taken by the Council of National Security" [i.e., the officers who undertook the coup]. 
which finds itself more aligned with the civilian leadership, and could possibly be amenable to the idea of being subservient to civilian authority (Aydinli, 2011, pp. 235-37).

While the current Pakistani constitution does not have any immunity for the military officials in the same manner as Turkey, Pakistan's courts have typically condoned military interventions in the past. Each military intervention in Pakistan (with one exception) has received judicial sanction. The only exception to this has been the suspension of the Constitution and imposition of emergency by ex-President Musharraf in November 2007 for which he is currently facing trial. Even in that case, the judiciary first (through judges appointed by Musharraf) validated the suspension and emergency and only later revoked and overruled its earlier decision (as the judges deposed by Musharraf had resumed office). In fact, judicial sanction has performed an important function for military governments, bestowing legitimacy on them, issuing declarations that the civilian dispensation had failed, and thereby perpetuating a warped civil-military relationship (Shah, 2014, p. 216). The Musharraf trial therefore also initiated a new precedent in the role of the judiciary in the civil-military equation. Whereas previously the military had been able to rely on judicial sanction for its intervention, in November 2007 the dynamic was different - Musharraf had tried to remove the incumbent Chief Justice and a popular movement had started for his restoration. After his restoration, there was no hope of the judiciary and the military President seeing eye to eye, so Musharraf imposed the emergency and suspended the Constitution precisely to remove the troublesome judges (who at the time were hearing a challenge to his ability to continue to be President and contest Presidential elections while also being a serving Chief of Army Staff). Therefore, Musharraf stood no chance of his actions in November 2007 being given judicial sanction once the deposed judges were restored.

The current government initiated treason charges against Musharraf in November 2013 under Article 6 of the constitution ${ }^{5}$. Musharraf avoided appearing in court and being indicted for a protracted period, being holed up in a military hospital on the grounds of ill health and unfitness to attend court (which suggested the military's willingness to do what it could to help Musharraf avoid trial, without coming out openly against the Government). Eventually, he was charged and pled not guilty at his indictment earlier in 2014. His trial is currently ongoing. Interestingly, Musharraf was charged not for subverting the Constitution in his 1999 coup, but rather for the state of emergency imposed on November $3^{\text {rd }} 2007$ during his reign as President of Pakistan. The reason for this is that after the 1999 coup, the Supreme Court ratified the coup and once the parliament was restored it also approved all the constitutional and legislative amendments made during the Musharraf regime. This did not happen after the imposition of the state of emergency in November 2007. The lack of judicial and parliamentary sanction (mentioned above) for Musharraf's actions is a key reason why the Government chose to prosecute him for the November 2007 emergency and suspension of the Constitution and not for the original 1999 military coup and overthrow of the elected government.

Although the Constitution permits the imposition of the state of emergency, the unconstitutionality of Musharraf's actions (as per the government's case) lies in the fact that that he imposed the emergency in his capacity as the serving Chief of Army staff of the country as opposed to the President. Additionally, he suspended the Constitution outright, for which there is no provision ${ }^{6}$. However, the Musharraf trial, despite the theoretically and legally sound basis it rests on, has raised concerns among non-military quarters and outright outrage within military ranks. The most basic concern is the déjà vu arising from the similar players who were involved in 1999 - the party in power then and now is the Pakistan Muslim League N (PML N), and the Prime Minister then and now is Mian Nawaz Sharif. Nawaz Sharif was unceremoniously arrested following the success of the 1999 coup, and spent the subsequent 9 years in exile in Saudi Arabia. The possibility that this is merely an exercise in revenge rather than a bid to strengthen civilian control over the military is a very real concern. Another concern is that while Musharraf alone is being prosecuted for his actions, others involved are not ${ }^{7}$. This raises the very real question of whether the principle of accountability

${ }^{5}$ Article 6 of the constitution deals with high treason and declares that "any person who abrogates or subverts or suspends or holds in abeyance, or attempts or conspires to abrogate or subvert or suspend or hold in abeyance, the Constitution by use of force or show of force or by any other unconstitutional means shall be guilty of high treason".

6Under Article 232 of the Constitution, the State of Emergency suspends fundamental rights but not the constitution itself.

${ }^{7}$ Article 6 also declares that "any person aiding or abetting or collaborating" in the acts (defined as High Treason in clause (1) shall likewise be guilty of High Treason. 
remains equally effective unless it is applied to the military as an institution and to all those involved in the unconstitutional actions regardless of their institutional affiliation (Shah, 2014, p. 278).

\section{Points of Divergence - one step forward, four steps back?}

Why is it that despite the invasive and controversial nature of the Ergenekon trials, they appear to have received a certain measure of cooperation from within the military that is noticeably absent from the Musharraf trial? The answer lies in the fact that there have been a few significant points of divergence between Pakistan and Turkey in the evolution of the civil-military dynamic, and as a consequence, how these trials have been received by both military and non-military quarters. The first goes back to the emergence from "the lost decade of the nineties" (Morris, 2006, p. 2) for both countries. Turkey emerged from this decade of weak coalition governments, a civil war and ideological battles and moved towards an era of reform, democratization, greater economic liberalization and a general opening up towards the world (Morris, 2006, p. 2). Pakistan, on the other hand, fell into a loosely disguised military dictatorship which set democratic development in the country back by at least a decade.

Another key point of divergence between the two countries is the performance of the civilian governments. Historically, the people of both Turkey and Pakistan - and indeed the militaries themselves - have perceived the military to be saviors of the last resort. Civilian political leadership has made an adequate case for military intervention by abysmally underperforming whenever they have been handed the mandate to govern. Rampant corruption, economic instability and mal-administration are significant features of most civilian administrations to date, particularly in Pakistan. The Erdoğan government, for the first time, appeared to provide a viable alternative to military rule in Turkish society. The party first swept into power by reaching out to groups within society that had historically been marginalized under military rule, making their stand much more inclusive than the inherent elitism and exclusivity of the military. They then supplemented this by transforming the economy from a struggling one to a booming one. Thus, even when Erdoğan and his government were suspected of being authoritarian - particularly during the Ergenekon trials - the first instinct of Turkish society was not to look towards the army for rescue - since no "rescue" was required. Rather, in the days following the revelations, arrests and resignations of the Ergenekon case, it was very much business as usual in the country. Pakistan, on the other hand, has failed to produce a similarly wellfunctioning government. The reign of the first democratically elected government post the Musharraf era while marked with significant legislative developments such as the passage of the $18^{\text {th }}$ amendment drastically underperformed in practically every other way in terms of governance. It would not be wrong to say that the biggest cause to celebrate the previous government would be that it managed to survive its constitutionally mandated five year period. The economy lies in tatters, the country is rife with terrorism, and the energy crisis is worse than ever. Democratic considerations then ring hollow for the average person and the military begins to look like a viable alternative.

Another significant point of divergence between the two is the alignment of interests between the military elites and civilian governments, in particular related to foreign policy. For most of Turkey, its civilian politicians and the armed forces - and all factions within - Europe is the goal. Turkey had to become more democratic in order to attain candidacy for EU membership in the second half of the 1990s, and when it became a candidate, it had to adopt sweeping political reforms in order to fulfill the EU's accession criteria so that accession negotiations could begin (Bac, 2005, p. 17). This milestone, and the fact that it was achieved by a democratically elected civilian government, is significant in two ways. First, societal memory will remember that it was Erdoğan, rather than a military leader who managed to bring Turkey to this landmark. And second, in order to be a serious contender for membership, democratic backsliding is not an option. Pakistan on the other hand is a fundamentally different story. The military has historically used the external threat posed by India - and to an extent Afghanistan - to justify its generous budget. Foreign affairs, therefore, especially as it relates to the United States, India, and Afghanistan, constitutes an important concern of the military (Singh \& Hickman, 2013, p. 47). Failure of civilian governments to factor this into their external dealings can and will be costly. The current government, on taking power, has generally kept a pro-India stance and there have been talks about developing economic ties with India. The lack of any engagement and consultation with the military in reaching this decision is likely to create unhappiness in military quarters. 
The most important point of divergence between Turkey and Pakistan, however, is the way in which the Turkish military has adapted to the larger paradigm shift in the civil military dynamic in the state, and its perception of it in the society. Divisions within military ranks are becoming more pronounced i.e. between "gradualists" - the progressive elements within the military - by refusing to cooperate with the "absolutist" traditional defenders of Kemalism. On the one hand, any coup plans have not materialized mostly because the "gradualists" by refusing to cooperate with the "absolutist" coup planners, have blocked such an attempt. On the other hand, the Ergenekon operation itself has materialized and continued due to the gradualists' informal and formal cooperation with the soft realm-a cooperation apparent in their failure to react negatively to the arrests of retired and serving officers, and their willingness to remain respectful of the judicial process (Aydinli, 2011, p. 228). There do not appear to similar divisions among the Pakistani military. At the highest level of the military, shared decision making and collective responsibility prevails and preserves the unity of command (Shafqat, 2011, pp. 50-53). Importantly, the military's involvement in active combat in military operations against terrorists in the north-west of the country also reduces any room for divisions within the military.

\section{Conclusion}

It is clear that moving forward, consolidating democracy in both Turkey and Pakistan must take into account the resistance that military organizations in both countries are likely to put up (Singh \& Hickman, 2013, p. 48). The Turkish military, due largely to a viable alternative in terms of governance and pragmatic concerns regarding Turkey's position on the international sphere is moving towards a more democratic society, and a more equitable civil-military dynamic. This, in large part, is facilitated by the divisions from within the Turkish military which see a different, more evolved role for the military vis a vis the state and civilian leadership. Optimistically, it might be a fair assessment to say that Turkey has made significant inroads towards rectifying its civil-military imbalance and that the era for military coups - direct or otherwise - is finally over in Turkey. On a more sobering note, however, it is important to note that while the role of the military in politics has lessened, Turkey is by no means ready for true democratic consolidation. Authoritarianism, high-handedness and dictatorial tendencies from civilian governments have the potential to undercut the country's hard earned democratic reforms. Going forward then, more democracy, greater prospects for European Union membership, enhanced political stability and continuing economic growth will further reduce the military's political influence and lead Turkey towards true democratic consolidation (Narli, 2000, p. 121).

The Pakistani military conversely, very much remains a power player, albeit a behind the scenes one ${ }^{8}$. At a societal level, the 2007 movement for the restoration of the judiciary, which turned into a movement for the removal of Musharraf's military government, has had the unintended effect of broadly delegitimizing direct military rule as a solution to Pakistan's political and economic problems (Shah, 2014, p. 276). However, indirect interference is no less potent when it serves to render a civilian government powerless in front of the military. Moreover, there appears to be very little evolution from within the military towards a more civilian controlled setup. In stark contrast to Turkey, the lack of effective governance in domestic affairs, and no overarching democratizing foreign policy imperative also reduce the internal and external push factors that could result in reduced involvement of the military. Perhaps that is why Pakistan's trial of ex-President Pervez Musharraf is unlikely to be as successful as the Turkish experience. In fact, many analysts have already stated that the protests rocking Pakistan's Federal Government since August 2014 with allegations of rigging in last year's general elections are part of the military's push back and re-assertion of control. Pakistan it seems still has some distance to travel - but the one factor in control of the current government is to improve domestic governance.

\footnotetext{
8 The five year reign of the Pakistan Peoples Party (PPP) led government appears to have been an anomaly, particularly in light of recent events (see note 1). The PPP has historically had a turbulent relationship with the military, stemming from the execution of the party's founder Zulfiqar Ali Bhutto under General Zia's military regime in 1979.
} 


\section{References}

AlJazeera. (2012). Timeline: A history of Turkish coups. Retrieved July 15, 2014, from Al Jazeera: http://www.aljazeera.com/news/europe/2012/04/20124472814687973.html

Aydinli, E. (2009). A Paradigmatic Shift for the Turkish Generals and an End to the Coup Era in Turkey. The Middle East Journal, 63(4), 581-596.

Aydinli, E. (2011). Ergenekon, New Pacts, and the Decline of the Turkish Inner State. Turkish Studies, 12(2), 227-239.

Bac, M. M. (2005). Turkey's Political Reforms and the Impact of the European Union. South European Society and Politics, 10(1), 16-30.

Bilgin, F. (2010). Turkey's 'Constitutional Moment'. Retrieved August 1, 2014, from The Washington Review of Turkish and Eurasian Affairs: http://www.thewashingtonreview.org/articles/constitutionalmoment.html

Cook, S. A. (2012). Turkey's Lesson for Egypt: Don't Prosecute Your Military Rulers (Yet). Retrieved July 25, 2014, from The Atlantic: http://www.theatlantic.com/international/archive/2012/04/turkeyslesson-for-egypt-dont-prosecute-your-military-rulers-yet/255666/

Dalay, G. (2013). The Ergenekon Coup Trials' Verdict: A Message from Turkey for Egypt's Coup Generals? Retrieved July 15, 2014, from Huffington Post: http://www.huffingtonpost.com/galip-dalay/theergenekon-coup-trials_b_3920777.html

Kuru, A. T. (2012). The Rise and Fall of Military Tutelage in Turkey: Fears of Islamism, Kurdism, and Communism. Insight Turkey, 14(2), 37-57.

Morris, C. (2006). The New Turkey: The Quiet Revolution on the Edge of Europe. London: Granta Books.

Narli, N. (2000). Civil-military relations in Turkey. Turkish Studies, 1(1), 107-127.

Perlmutter, A. (1969). The Praetorian State and the Praetorian Army: Toward a Taxonomy of Civil-Military. Comparative Politics, 1(3), 382-404.

Pope, N. P. (2011). Turkey Unveiled: A History of Modern Turkey. New York: Overlook Press.

Sattar, B. (2001). Pakistan: Return to Praetorianism. In M. Alagappa, Coercion and Governance: The Declining Role of the Military in Asia (pp. 385-412). Stanford University Press.

Shafqat, S. (2011). Pakistan's Military: The Challenge of Sustaining Democracy in Pakistan. Retrieved August 1, 2014, from The Islamic Monthly: http://digitaleditions.sheridan.com/publication/?i=61078\&pre=1

Shah, A. (2014). The Army and Democracy. Boston: Harvard University Press.

Siddiqa, A. (2007). Military Inc: Inside Pakistan's Military Economy. London: Pluto.

Singh, C. \& Hickman, J. (2013). Soldiers as Saviors of the State: The Cases of Turkey and Pakistan Contrasted. Journal of Third World Studies, 30(1), 39-54. 